\title{
PRASA JAKO ELEMENT BUDOWANIA RELACJI Z WŁADZAMI W PRAKTYCE KOŚCIOŁÓW MARIAWICKICH W LATACH 1907-1939
}

DOI: http://dx.doi.org/10.12775/TiCz.2021.023

\begin{abstract}
Streszczenie. Celem artykułu jest przedstawienie działań Kościołów mariawickich w zakresie budowania i podtrzymywania dobrych relacji z władzami państwowymi i partyjnymi w latach 1907-1939. Istotną rolę w tym procesie odegrała wydawana przez mariawitów prasa. Badania przeprowadzono przy pomocy opisu i krytycznej analizy zachowanych źródeł historycznych oraz analizy przekazów medialnych jako materiałów historycznych.
\end{abstract}

Słowa kluczowe: prasa; mariawici; relacje z władzami.

Abstract. The Role of the Press in Establishing Relations with Authorities in the Practice of Mariavite Churches in 1907-1939. The aim of the article is to present the activities of Mariavite churches aimed at establishing and maintaining good relations with state and party authorities in the years 1907-1939. The press titles published by the Mariavites played an important role in that process. The research involved describing and critically appraising the surviving historical sources as well as analyzing media messages as historical materials.

Keywords: press; Mariavites; relation with the authorities. 


\section{POCZAZTKI MARIAWITYZMU}

Mariawicką wspólnotę stanowią dwa wyznania. Pierwsza z nich Kościół Starokatolicki Mariawitów w RP z siedzibą w Płocku liczy 22,7 tys. wiernych, druga - Kościół Katolicki Mariawitów w RP z siedzibą w Felicjanowie ma 1,8 tys. wiernych ${ }^{1}$. Na ich genezę składają się warunki polityczne po klęsce powstania styczniowego, kiedy to rosyjski zaborca wprowadził w Królestwie Polskim szereg represji, np. kasatę klasztorów, zamkniecie seminariów duchownych. Częściowo przyczyniło się to wystąpienia kryzysu w Kościele Rzymskokatolickim. Należy jednak zaznaczyć, że posługa kapłańska, m.in. głoszenie słowa bożego, udzielanie sakramentów świętych, była sprawowana. W tych warunkach, w odpowiedzi na potrzeby duchowe społeczeństwa, polski kapucyn i teolog Honorat Koźmiński podjął się zakładania ukrytych instytutów życia konsekrowanego. W 1883 r. do jednego z nich wstąpiła Feliksa Kozłowska ${ }^{2}$. Niedługo później założyła w Płocku Zgromadzenie Sióstr Ubogich św. Matki Klary. Wstępując do niego przybrała zakonne imiona Maria Franciszka.

Początki mariawityzmu jako ruchu odnowy w Kościele, a następnie jako wyznania związane są z objawieniami, jakich doznała M.F. Kozłowska. Pierwsze z nich nastąpiło 2 sierpnia 1893 r. podczas modlitwy w przyseminaryjnym kościele św. Jana Chrzciciela w Płocku. Treść objawień związana była z powierzeniem M.F. Kozłowskiej misji odnowy moralnej duchowieństwa przez stosowanie różnych form kultu maryjnego. Jedną z nich było założenie Zgromadzenia Kapłanów Mariawitów ${ }^{3}$. W jego skład weszli rzymskokatoliccy księża, którzy postawili sobie za cel przeciwdziałanie kryzysowi przez odnowienie życia religijnego w Królestwie Polskim i pogłębienie życia duchowego kapłanów.

Po nieudanej próbie zatwierdzenia ruchu przez hierarchię kościelną i ekskomunikowaniu w 1906 r. M.F. Kozłowskiej i Jana Marii Micha-

1 Rocznik Statystyczny Rzeczypospolitej Polskiej, GUS, Warszawa 2020, s. 198; Zob. Wyznania religijne w Polsce 2015-2018, GUS, Warszawa 2019.

2 M.F. Kozłowska otrzymała na chrzcie imiona Feliksa Magdalena, ale używała także imienia Felicja.

${ }^{3}$ Nazwa „mariawita” została utworzona od łacińskich słów „Marie vita”, które oznaczają „życie Marii”. A. Górecki, Mariawici i mariawityzm - narodziny i pierwsze lata istnienia, Warszawa 2011, s. 373. 
ła Kowalskiego jako liderów mariawickich zwrócono się do Ministerstwa Spraw Wewnętrznych Rosji. Złożono wówczas spis statutów Związku Mariawitów Nieustającej Adoracji Ubłagania, aby rząd Rosji nie był przeciwny Związkowi ${ }^{4}$. W rezultacie w listopadzie 1906 r. Rada Ministrów Cesarstwa Rosyjskiego przyjęła rozporządzenie pt. O wydaniu tymczasowych przepisów, dotyczących sekty mariawickiej ${ }^{5}$, które gwarantowało mariawitom legalność działania i prawną odrębnośćc. Władzę w Związku Mariawitów pełnił Minister Generalny. Od 1907 r. był nim ks. J.M.M. Kowalski ${ }^{7}$. Kolejne uregulowania znalazły się w Ustawie Parafii Mariawickich z 1909 r. i dotyczyły konstruowania statutów parafii ${ }^{8}$.

Dalszy rozwój Kościoła mariawickiego umożliwiło przyjęcie mariawitów do Unii Utrechckiej, zrzeszającej Kościoły starokatolickie i wyświęcenie J.M.M. Kowalskiego na biskupa w 1909 r. Tym samym uzyskano sukcesję apostolską, która pozwalała biskupowi wyświęcać księży9 . Elementem umacniania władzy bp. J.M.M. Kowalskiego było ustanowienie go przez cara Mikołaja II w 1910 r. zwierzchnikiem Kościoła mariawickiego i przyznanie prawa do reprezentowania go wobec państwa ${ }^{10}$. Dalsze uregulowania prawne znalazły się w przyjętym w 1912 r. przez Radę Państwową i Dumę Państwową Cesarstwa Rosyjskiego Prawie o wyznaniu

${ }^{4}$ H. Seweryniak, Święte Oficjum a mariawici, Płock 2014, s. 71, 386.

${ }^{5} \mathrm{O}$ wydaniu tymczasowych przepisów, dotyczacych sekty mariawickiej, Zbiór Praw i Rozporządzeń b. ces. rosyj. wyd. przez Rządzący Senat z 26 XII 1906 r., nr 296, cz. 1, poz. 2080, s. 3971-3972.

6 Tamże, Biblioteka Prezydencka w Petersburgu (dalej BPP), Rossijskij Gosudarstwiennyj Istoriczeskij Archiw w Petersburgie (dawniej Centralnyj Gosudarstwiennyj Istoriczeskij Archiw w Leningradie), Sowiet ministrow (1905-1917), fond 1276.

7 S. Rybak, Mariawityzm. Dzieje i współczesność, Warszawa 2011, s. 66-67.

8 Ustawa Parafii Mariawickich, za: J. Sawicki, Stan prawny Kościoła Mariawitów, „Gazeta Administracji i Policji Państwowej” 7 (1935), s. 230-231; Archiwum Akt Nowych (dalej: AAN), Ministerstwo Wyznań Religijnych i Oświecenia Publicznego (dalej: MWRiOP), Sekty katolickie mariawici, sygn. 1431, Statut cerkiewnej gminy/parafii mariawitów, k. 40-46. Zob. H. Świątkowski, Wyznania religijne w Polsce ze szczególnym uwzględnieniem ich stanu prawnego. Część I. Wyznania i związki religijne, Warszawa 1937, s. 207-212.

9 S. Rybak, dz. cyt., s. 67-69.

10 S. Grelewski, Wyznania protestanckie i sekty religijne w Polsce współczesnej. Zarys stanu prawnego wyznań religijnych $w$ Polsce, Sandomierz 1935, s. 95-96; H. Świątkowski, dz. cyt., s. 211. 
mariawitó $w^{11}$. Przychylność władz rosyjskich dla mariawityzmu - manifestowana m.in. przez udekorowanie J.M.M. Kowalskigo krzyżem św. Jerzego i orderem św. Anny osobiście przez Mikołaja II - wiązała się z planami osłabienia katolicyzmu i ułatwienia ekspansji prawosławia w Królestwie Polskim ${ }^{12}$. Nie ma dowodów na inspirowanie przez rząd carski powstania ruchu mariawickiego, ale dokumenty archiwalne potwierdzają wspieranie mariawitów w celu osłabienia Kościoła rzymskokatolickiego ${ }^{13}$.

Także wydawane czasopisma od początku były dla mariawitów elementem budowania dobrych relacji z władzami rosyjskimi. Potwierdzają to charakterystyki cenzorskie pierwszego czasopisma mariawickiego, wydawanego w Łodzi, „Mariawity. Czciciela Przenajświętszego Sakramentu” (1907-1913) wraz z dodatkiem „Wiadomości” (1907-1908) oraz czasopisma „Wiadomości Mariawickie” (1909-1914). W corocznych sprawozdaniach inspektor do spraw druku Wasilij Pietrow podkreślał lojalność wydawcy wobec rządu rosyjskiego, pozytywny stosunek do cerkwi prawosławnej oraz nieangażowanie się w sprawy polityczne ${ }^{14}$.

\section{STOSUNEK DO WŁADZ RP I WIZJA PAŃSTWA W PRASIE MARIAWICKIEJ DO ŚMIERCI MARSZAŁKA PIŁSUDSKIEGO}

U progu niepodległości przywódcy mariawiccy stanęli przed koniecznością nawiązania dobrych relacji z władzami tworzonego państwa polskiego. W tym celu podczas spotkania z Józefem Piłsudskim bp Filip Feldman zapoznał go z objawieniami M.F. Kozłowskiej i ideami mariawityzmu. Uzyskał zapewnienie o niedopuszczeniu do jakichkolwiek prze-

11 AAN, MWRiOP, 1918-1935, Sekty katolickie mariawici, sygn. 1431, Prawo z dnia 11 III 1912 r. o mariawitach. O wyznawcach nauki mariawickiej. Odpis, k. 25; J. Sawicki, dz. cyt., s. 231-232.

12 G. Skwara, Mariawici. Szkic historyczny ruchu mariawickiego w Polsce, Płock 1925, s. 9-12; A.J. Nowowiejski, Płock. Monografia historyczna, wyd. II, Płock 1930, s. 667; M.M. Szejnman, O stanowisku Watykanu w kwestii polskiej w końcu XIX - początku XX w., „Studia z Dziejów Kościoła Katolickiego” 2 (1960) 2, s. 18; T. Toborek, Problem mariawityzmu na łamach „Gońca Częstochowskiego”. Echa zajść w Strykowie w 1906 r., „Rocznik Łódzki” 45 (1998), s. 228.

13 A. Górecki, dz. cyt., s. 373.

14 Prasa Królestwa Polskiego w opinii władz cenzury rosyjskiej, s. 28, 53, 66, 76, $100,113$. 
śladowań mariawitów w imię tolerancji religijnej. Wyrazem wdzięczności było odprawienie w świątyniach mariawickich specjalnych mszy za zdrowie Piłsudkiego ${ }^{15}$.

Uzyskanie przychylności władz państwowych okazało się jednym z priorytetów wspólnoty. Po odzyskaniu przez Polskę niepodległości sytuacja prawna mariawitów nie była bowiem jasna, mogli oni prowadzić działalność tylko na terenach byłego zaboru rosyjskiego w ramach dawnego prawa. Na terenach byłych zaborów pruskiego i austriackiego nie było to możliwe z uwagi na brak stosownych aktów prawnych. Uregulowania dokonano dopiero w 1930 r., kiedy to Ministerstwo Wyznań Religijnych i Oświecenia Publicznego wymieniło Staro-Katolicki Kościół Mariawitów wśród wyznań prawnie uznanych, których stosunek do państwa nie został ustawowo uregulowany ${ }^{16}$.

Po śmierci M.F. Kozłowskiej w 1921 r. J.M.M. Kowalski ogłosił się arcybiskupem i rozpoczął radykalne zmiany w Kościele ${ }^{17}$. Należało do nich m.in. kapłaństwo kobiet oraz dopuszczenie zawierania małżeństw pomiędzy księżmi a siostrami mariawickimi, co spotkało się z niechęcią wiernych i duchownych ${ }^{18}$. Wskutek wewnętrznego konfliktu w 1935 r. doszło do rozłamu na dwa wyznania: Staro-Katolicki Kościół Mariawitów z bp. F. Feldmanem na czele i Kościół Katolicki Mariawitów, któremu przewodził abp J.M.M. Kowalski.

Wydawcy mariawiccy nie ukrywali swoich sympatii i antypatii politycznych. W 1923 r. w „Jednodniówce Mariawickiej”, wyjaśniając aktualną sytuację w Polsce biskupi i kapłani mariawiccy wyraźnie opowiadali się za obozem ludowo-robotniczym, tworzonym przez PSL „Wyzwolenie”, Jedność Ludową, Polską Partię Socjalistyczną i Narodową Partię Robotniczą. Drugi zaś obóz charakteryzowali jako: „obóz księżo-pański, zwany dziś słusznie Chjeną, [...] całkowicie wrogim Bogu i zgubny dla naszego

15 G. Skwara, dz. cyt., s. 18.

16 AAN, MWRiOP, Międzywyznaniowe: statystyka i wykazy kościołów i związków religijnych w Polsce z zaznaczeniem ich podstaw prawnych 1928, 1930-1932, 1934-1935, 1936, 1937-1938, sygn. 376, Pismo Ministerstwa Wyznań Religijnych i Oświecenia Publicznego w sprawie stanu prawnego wyznań w państwie z dnia 18 X 1930 r., k. 8-9.

17 Zob. E. Warchol, dz. cyt., s. 43-70.

18 R.A. Podgórski, Starokatolicki Kościół Mariawitów. Studium historyczno-socjologiczne, Kraków 1998, s. 50. 
narodu"19. Udzielając poparcia obozowi Piłsudskiego, liczono na prawne uregulowanie sytuacji mariawitów. Drugi z obozów, przeciwny mariawitom, nie dawał na to szans. Zaangażowanie polityczne biskupów mariawickich nie było dobrze widziane. Poseł jednego ze stronnictw ludowych krytykował postawę wydawcy: „Po co było tak się angażować do polityki i jawnie wypowiadać swoje sympatie w kierunku lewicy. Obniżyliście przez to swoją powagę. Wy powinniście wpatrywać się w wiekuiste prawdy i te prawdy głosić; a prawdy polityczne są przemijające: dziś głosimy jedno, a jutro temu może będziemy przeczyć" ${ }^{20}$. W czasopismach rzymskokatolickich wątpiono w szczerość zaangażowania mariawitów w sprawy państwa i zarzucano koniunkturalizm ${ }^{21}$.

Przywódcy mariawiccy postępowali jednak konsekwentnie. W numerze "Jednodniówki Mariawickiej”, wydanej w związku z przewrotem majowym w 1926 r., zamach stanu Piłsudskiego przyjęto z zadowoleniem, zaś Marszałek został przedstawiony jako wykonawca woli Bożej, ratujący państwo. Autor apeluje o posłuszeństwo i wsparcie dla Piłsudskiego, który na gruzach upadłego świata ma zbudować Królestwo Boże na Ziemi ${ }^{22}$.

W publikowanych wypowiedziach widoczne jest zainteresowanie sprawami państwowymi. W „Jednodniówce Mariawickiej” ukazał się cykl tekstów autorstwa kapłana Zenona Marii Jakuba Łuszczewskiego zawierających wizję państwa. Opowiadał się on za rozdzieleniem państwa od Kościoła i jednocześnie za poszanowaniem praw moralnych ustanowionych przez Boga i zawartych w Ewangelii, co miało być gwarancją sprawnie funkcjonującego ustroju społecznego. Autor postuluje, aby wydatki na utrzymanie duchowieństwa przekazywać ubogim. Opowiada się za upaństwowieniem kopalń w celu poprawienia losu robotników ${ }^{23}$.

Jednym z celów pisma pt. „Królestwo Boże na Ziemi” było zapewnienie Kościołowi przychylności władz. Podczas wyborów parlamentar-

19 Odezwa mariawickiego duchowieństwa do ludzi dobrej woli, „Jednodniówka Mariawicka” 1 (1923), s. 1.

20 O. M. Bartłomiej [W.M.B. Przysiecki], Dialogi polityczne, „Jednodniówka Mariawicka" 5 (1924), s. 2.

${ }^{21}$ Sprawozdanie $z$ ruchu religijnego, naukowego i społecznego, „Przegląd Powszechny" 172 (1926), s. 113-114.

22 „Jednodniówka Mariawicka” 6 (1926), s. 1.

23 [Z.]M.J. Łuszczewski, Państwo i Ewangelia, „Jednodniówka Mariawicka” 6 (1935), 17 III, s. 42-43. 
nych w 1928 r. na łamach czasopisma abp J.M.M. Kowalski namawiał do głosowania na listę Bezpartyjnego Bloku Współpracy z Rządem, uznając to za wyraz woli Bożej ${ }^{24}$. Po zwycięstwie tego ugrupowania pisano, że jako jedyne reprezentuje ono ideę państwową ${ }^{25}$. Podczas przedterminowych wyborów parlamentarnych w 1930 r. abp J.M.M. Kowalski ponownie wzywał do głosowania na BBWR. Nie powstrzymywał się przed wywieraniem presji, ostrzegając, że oddanie głosów na inną partię będzie grzechem $^{26}$.

Także po rozłamie w mariawityzmie abp J.M.M. Kowalski wyrażał na łamach pisma swoje sympatie polityczne. $Z$ aprobatą wypowiadał się o działaniach rządu premiera Felicjana Sławoja Składkowskiego, opublikowal jego przemówienie na temat spraw społecznych i podatkowych ${ }^{27}$. Zaangażowanie w sprawy polityczne i lojalność wobec władzy redakcja „Królestwa Bożego na Ziemi” wyjaśniała zasadami wyrażonymi w Liście do Rzymian apostoła Pawła, w którym zapisano, że władza świecka pochodzi od Boga i dlatego należy się jej posłuszeństwo. W związku z tym mariawici, pomimo doznanych krzywd, pozostają lojalni wobec władz państwa ${ }^{28}$.

\section{RELACJE Z WŁADZAMI I PODTRZYMYWANIE TRADYCJI NIEPODLEGŁOŚCIOWEJ W LATACH 1935-1939}

Po śmierci Piłsudskiego redakcja „Królestwa Bożego na Ziemi” skierowała swoje sympatie ku Edwardowi Śmigłemu-Rydzowi i jego obozowi. Ich wyrazem było na przykład opublikowanie deklaracji programowej płk. Adama Koca, która 21 lutego 1937 r. została wyemitowana w radiu. Zawierała cele ideowe i polityczne Obozu Zjednoczenia Narodowego tworzonego w celu wzmocnienia obronnego potencjału Rzeczypospoli-

${ }^{24}$ Wezwanie do wyborów arcybiskupa mariawitów, „Królestwo Boże na Ziemi” 1928, nr 11, 3 III, s. 88.

25 Wyniki wyborów, „Królestwo Boże na Ziemi” 12 (1928), 10 III, s. 96.

26 „Królestwo Boże na Ziemi” 41 (1930), 9 X, s. 328.

27 Złote promienie mowy p. premiera Składkowskiego, „Królestwo Boże na Ziemi” 1 (1937), 1 I, s. 10.

${ }^{28}$ Mariawitki szerza silnq agitację, „Królestwo Boże na Ziemi” 5 (1937), 1 II, s. $6-8$. 
tej i mającego stanowić zaplecze polityczne Śmigłego-Rydza ${ }^{29}$. Temat ten rozwijano w następnym numerze pisma. W artykule pt. Mariawici a deklaracja pułk. A. Koca starano się udowodnić, że idea utworzenia Obozu Zjednoczenia Narodowego jest wypełnieniem się objawień M.F. Kozłowskiej. Program płk. Koca wpisano w ideę tworzenia Królestwa Bożego na Ziemi, w którym Polska będzie pełniła rolę mesjasza. Śmigły-Rydz został $\mathrm{w}$ artykule zaprezentowany jako spadkobierca myśli Piłsudskiego ${ }^{30}$.

Poparcie dla rządu Rzeczypospolitej wyrażano także na łamach czasopisma pt. „Dzieje Królestwa Bożego na Ziemi” wydawanego nakładem Wydawnictwa Kapłaństwa Ludowego Kościoła Katolickiego Mariawitów. W informacji na temat zmian w rządzie przywoływano postać Piłsudskiego, którego duch miałby kierować działaniami powołanego na premiera Składkowskiego. Wyrażano nadzieję, że krzywdy wyrządzone mariawitom zostaną naprawione ${ }^{31}$. Redakcja otwarcie deklarowała sympatię do premiera. W czasopiśmie odnotowano przeglądy podległych mu urzędów, samego premiera przedstawiono jako dobrego i sprawiedliwego gospodarza $^{32}$. Zamieszczano jego wystąpienia sejmowe, chwalono społeczny program walki z bezrobociem i ubóstwem ${ }^{33}$. Na łamach pisma popierano pomysł pozyskiwania pozabudżetowych środków finansowych na dozbrojenie armii przez utworzenie Funduszu Obrony Narodowej w 1936 r. ${ }^{34} \mathrm{Z}$ sympatią odnoszono się do postaci Ignacego Mościckiego z okazji dziesięciolecia prezydentury ${ }^{35}$. Wyłącznie w pozytywnym świetle ukazywano gen. E. Śmigłego-Rydza jako Generalnego Inspektora Sił Zbrojnych, podkreślając jego zasługi dla Polski.

Na łamach „Dziejów Królestwa Bożego na Ziemi” utrwalano pamięć o ważnych wydarzeniach narodowych. W publikowanych spra-

${ }^{29}$ Deklaracja pułkownika Adama Koca, „Królestwo Boże na Ziemi” 7 (1937), s. 8.

30 Mariawici a deklaracja pułk. A. Koca, „Królestwo Boże na Ziemi” 8 (1937), 28 III, s. 8.

31 Zmiany w Rzq̨dzie, „Dzieje Królestwa Bożego na Ziemi” 1 (1936), s. 7.

32 Premier Składkowski patroluje, „Dzieje Królestwa Bożego na Ziemi” 2 (1936), s. 16.

${ }^{33}$ Mowa premiera Składkowskiego w Sejmie, „Dzieje Królestwa Bożego na Ziemi” 3 (1936), s. 8.

${ }^{34}$ Dekret Prezydenta Rzeczypospolitej z dnia 9 kwietnia 1936 r. o Funduszu Obrony Narodowej. Dz.U. 1936 nr 28 poz. 225.

35 Polska a zbrojenia, „Dzieje Królestwa Bożego na Ziemi” 1 (1936), s. 7-8; Uroczystość jubileuszowa Pana Prezydenta, „Dzieje Królestwa Bożego na Ziemi” 1 (1936), s. 8. 
wozdaniach z obchodów rocznic „cudu nad Wisłą" przekonywano, że do zwycięstwa nad bolszewikami przyczyniła się M.F. Kozłowska, składając Jezusowi ofiarę swojego życia ${ }^{36}$. Mimo otwartego popierania rządu na łamach prasy mariawici nie uzyskiwali istotnych korzyści.

Obie wspólnoty mariawickie przywiązywały dużą wagę do wychowania obywatelskiego. W tekstach zamieszczanych na łamach czasopisma „Młody Mariawita”, wydawanego przez Staro-Katolicki Kościół Mariawitów, propagowano postawę wierności przekonaniom, przełożonym i ojczyźnie. Do obowiązków młodzieży należało zdobywanie wiedzy jako podstawy do świadomego uczestnictwa we wspólnocie religijnej i państwowej ${ }^{37}$.

Na łamach „Młodego Mariawity” podtrzymywano tradycję niepodległościową. Upamiętniono na przykład rocznicę odzyskania niepodległości przez Polskę w 1918 r. ${ }^{38}$ Wpisywano je w misję narodu polskiego, który miał przewodzić innym narodom w drodze do Królestwa Bożego na Zie$\mathrm{mi}^{39}$. O szczególnej roli Polski miały świadczyć jej męczeńskie dzieje, wizje narodowych wieszczów oraz objawienia M.F. Kozłowskiej ${ }^{40}$. Opis obchodów rocznicy odzyskania niepodległości w klasztorze w Felicjanowie zamieszczono w jednym $\mathrm{z}$ numerów pisma. Uroczystości rozpoczęła msza w intencji Polski, rządu i narodu. Zorganizowano odczyt na temat dziejów Polski i jej drogi do niepodległości oraz koncert pieśni patriotycznych ${ }^{41}$.

W wypowiedziach zamieszczanych w „Młodym Mariawicie” uwidacznia się kult Piłsudskiego, przedstawianego w roli męża opatrznościowego, który realizuje Boży plan. Polska jawi się w nim jako mesjasz narodów. Na łamach pisma Marszałek przedstawiany jest wyłącznie pozytywnie, nawet zamach w 1926 r. ukazano jako przejaw walki ze złem².

36 16-ta rocznica „cudu nad Wisła”, „Dzieje Królestwa Bożego na Ziemi” 5 (1936), s. 48. Kronika, „Dzieje Królestwa Bożego na Ziemi” 5 (1936), s. 48.

3710 przykazań Młodego Mariawity, „Młody Mariawita” 9 (1937), s. 2-3.

38 Pamiętaj, „Młody Mariawita” 1937, 29 XI, s. 2 okładki.

39 M.I., W 19-ta rocznice odzyskania niepodległości, „Młody Mariawita” 1937, 29 XI, s. 2-3.

40 Posłannictwo naszej Najdroższej Mateczki i Najczcigodniejszego Brata Abpa Michała $w$ dziejach Polski, „Młody Mariawita” 1937, 29 XI, s. 7-10.

${ }^{41}$ Obchód Święta Niepodległości Polski w centrum Mariawityzmu - Felicjanowie, „Młody Mariawita” 1937, 29 XI, s. 10-12.

42 Twórca Polski Niepodległej Marszałek Józef Piłsudski, „Młody Mariawita” 1937, 29 XI, s. 3-6. 
W podobnym świetle ukazywano Rydza-Śmigłego. Z okazji imienin zamieszczono jego życiorys, w którym nadano mu bohaterski rys. Pisano, że z tej okazji w klasztorze w Felicjanowie odbyły się specjalne uroczystości, na które składały się msza i koncert pieśni. Ogród i zabudowania klasztorne zostały ozdobione kwiatami i iluminacjami: „Od góry, z balkonu domu klasztornego, padał duży snop światła, z którego wyłaniała się postać Dostojnego Solenizanta, w obramowaniu wieńca z szarfami i różnobarwnych lamp"43.

O zaangażowaniu obywatelskim mariawitów świadczyło włączanie się w akcje państwowe, co widoczne jest w wypowiedziach na łamach prasy mariawickiej. Na przykład w ramach integrowania armii z ludnością cywilną mariawici z Sobótki urządzili śniadanie dla jednego z plutonów 8 kompanii 37 pułku piechoty ziemi łęczyckiej stacjonującego w Kutnie. Żołnierze po wspólnym posiłku wysłuchali programu artystycznego, a następnie zwiedzili zabudowania parafialne $e^{44}$. Innym przykładem zaangażowania było zamieszczenie na łamach pisma apeli o upamiętnienie wydarzeń i bohaterów wojny polsko-bolszewickiej. Zwracano się o przysyłanie pamiątkowych materiałów oraz o spisywanie wspomnien ${ }^{45}$.

Wydawcy mariawiccy niejednokrotnie udzielali poparcia dla działań rządu. Na przykład po zajęciu Zaolzia przez Polskę w 1938 r. redakcja "Głosu Staro-Katolickiego" zamieściła szereg artykułów. Temat rozpoczynał tekst pod wymownym tytułem 600-letnia niewola Zaolzia kończy się ${ }^{46}$. $\mathrm{W}$ kolejnych numerach $\mathrm{z}$ entuzjazmem komentowano wkroczenie wojska polskiego na teren Czechosłowacji ${ }^{47}$. Opisywano proces przejmowania władzy ${ }^{48}$. Przy okazji opublikowano cykl na temat historii stosunków polsko-czeskich ${ }^{49}$. Zamieszczono słowa działacza PPS Adama Próchnika, według którego przyłączenie Śląska Cieszyńskiego do Polski było aktem sprawiedliwości historycznej ${ }^{50}$. Na łamach pisma opublikowano list Syno-

43 Współtwórca Niepodległej Polski, „Młody Mariawita” 1938, 17 IV, s. 4-7.

${ }^{44}$ Kronika mariawicka, „Głos Staro-Katolicki” 22 (1938), s. 349.

${ }^{45}$ Komunikat nr 3, „Głos Staro-Katolicki” 22 (1938), s. 352.

46 600-letnia niewola Zaolzie kończy się, „Głos Staro-Katolicki” 34 (1938), s. 537.

47 Ślask Zaolziański odzyskany!, „Głos Staro-Katolicki” 35 (1938), s. 554.

48 Dookoła Czechosłowacji, „Głos Staro-Katolicki” 36 (1938), s. 570-574.

49 Bp J. [J. Próchniewski], Z powodu powrotu Śląska za Olza do Macierzy, „Głos Staro-Katolicki” 36 (1938), s. 561-563; nr 37, s. 578-579.

50 „Głos Staro-Katolicki” 37 (1938), s. 584-586. 
du Kościoła do Prezydenta Rzeczypospolitej Polskiej, w którym składano mu hołd za stanowisko w sprawie Zaolzia ${ }^{51}$.

W czasopismach mariawickich kultywowano pamięć o przeszłości, przypominano o kolejnych rocznicach odzyskania niepodległości przez Polskę. Na przykład z okazji 20. rocznicy opublikowano mowę prezydenta Mościckiego oraz opisywano przebieg obchodów w płockiej wspólnocie. Obejmowały one uroczystą mszę z okolicznościowym kazaniem oraz patriotyczną akademię ${ }^{52}$.

Redakcja „Głosu Staro-Katolickiego” nie zapominała o osobach zasłużonych dla odzyskania niepodległości. Przykładowo po śmierci Romana Dmowskiego zamieszczono wypowiedź przedstawiającą zmarłego jako patriotę. Wskazano jednakże na popełnione przez niego błędy ${ }^{53}$. Po samobójczej śmierci Walerego Sławka przypomniano jego działalność i zasługi dla Polski ${ }^{54}$. Na łamach pisma publikowano wypowiedzi przedstawicieli władzy ${ }^{55}$.

Patriotyczna postawa mariawitów widoczna jest m.in. w wypowiedziach na łamach czasopism. Przykład stanowi odezwa biskupa F. Feldmana na łamach „Głosu Staro-Katolickiego”, który w 1939 r. w obliczu zagrożenia wojną zwrócił się do mariawitów o kupowanie obligacji obrony przeciwlotniczej i przekazywanie pieniędzy na Fundusz Obrony Narodowej $^{56}$. Atmosfera zbliżającej się wojny jest obecna także w innych wypowiedziach na łamach czasopisma. Na bieżąco informowano o zmieniającej się sytuacji. W obliczu zagrożenia apelowano o jedność narodową i zaniechanie sporów partyjnych ${ }^{57}$. Informowano o żądaniach Hitlera

51 Sprawozdanie z Synodu, „Głos Staro-Katolicki” 37 (1938), s. 588.

52 Mowa Pana Prezydenta Rzplitej w godzinę wielkiej Rocznicy, „Głos Staro-Katolicki” 41 (1938), s. 652-653; N, Obchód 20-lecia Niepodległości Polski przy naszej świątyni w Płocku, „Głos Staro-Katolicki” 41 (1938), s. 656.

53 W.P. [Wacław Przysiecki], Po zgonie Romana Dmowskiego, „Głos Staro-Katolicki" 5 (1939), s. 65-66.

54 Tenże, S.P. Walery Sławek, „Głos Staro-Katolicki” 16 (1939), s. 241-243.

55 Doniosła mowa wicepremiera Kwiatkowskiego w Katowicach, „Głos Staro-Katolicki” 38 (1938), s. 602-603; Mowa wicepremiera E. Kwiatkowskiego, „Głos Staro-Katolicki” 44 (1938), s. 700-701.

56 Odezwa Naczelnego Biskupa do Braci i Sióstr Mariawitów, „Głos Staro-Katolicki” 15 (1939), s. 226.

57 W.P. [W. Przysiecki], Trwałe podstawy jedności narodowej, „Głos Staro-Katolicki” 17 (1939), s. 257-259. 
Gdańska oraz korytarza do prowincji wschodniej. Zawiadamiano o zerwaniu paktu Niemiec i Polski podpisanego z Piłsudskim ${ }^{58}$. Zamieszczono fragmenty mowy ministra Józefa Becka w Sejmie, która zawierała negatywną odpowiedź na żądania Hitlera ${ }^{59}$. W ostatnim numerze „Głosu Staro-Katolickiego", który ukazał się z datą 3 września 1939 r. znalazła się informacja o sojuszu zawartym pomiędzy Polską a Anglią, a także o pakcie Ribbentrop - Mołotow ${ }^{60}$.

Podczas II wojny światowej mariawici ponieśli dotkliwe straty. Aresztowano wielu kapłanów, w tym redaktorów i autorów pism mariawickich, m.in. abp. J.M.M. Kowalskiego, który następnie zginął w komorze gazowej. Powodem zatrzymania było zamieszczanie na łamach „Królestwa Bożego na Ziemi” krytycznych wypowiedzi o Hitlerze. J.M.M. Kowalski dowodził polskości Pomorza Gdańskiego i żądał jego zwrotu ${ }^{61}$.

\section{PODSUMOWANIE}

Dla Kościołów mariawickich prasa stanowiła istotne narzędzie budowania i podtrzymywania relacji z władzami państwowymi w celu zapewnienia wspólnotom ciągłości istnienia. Na łamach prasy mariawickiej w latach 1907-1939 ujawnia się lojalność wobec państwowych władz Imperium Rosyjskiego i II Rzeczypospolitej. Utrzymywanie dobrych relacji z władzami wynikało zarówno z doktryny, która zakładała szacunek dla wszelkiej władzy, jak i z pragmatyzmu i troski o zachowanie trwałości Kościoła. W II Rzeczypospolitej prasa stanowiła jeden ze środków patriotycznego i obywatelskiego wychowywania mariawitów. Była narzędziem wsparcia władz państwowych. Redaktorzy i autorzy mariawiccy otaczali kultem charyzmatyczne postacie, m.in. J. Piłsudskiego. Jednak deklarowanie na łamach prasy lojalności wobec władz nie pozwoliło na uzyskanie przez nich silniejszej pozycji.

${ }^{58}$ Hitler zerwał pakt $z$ Polską, „Głos Staro-Katolicki” 19 (1939), s. 300-301.

59 Wielka mowa p. ministra Becka w Sejmie, „Głos Staro-Katolicki” 20 (1939), s. 313-315.

${ }^{60}$ Sojusz polsko-angielski, „Głos Staro-Katolicki” 36 (1939), s. 577; Pakt Sowietów z Rzesza, „Głos Staro-Katolicki” 36 (1939), s. 578-579.

${ }^{61}$ IPN, Lista ujawnionych osób zamordowanych $w$ Hartheim: Pozycja nr 514: Kowalski Jan, nr obozowy 24542, ur. 25.12.1871 r. w Latowiczu, data wywózki 18.05.1942 r. 


\section{BIBLIOGRAFIA}

\section{Źródła archiwalne}

Archiwum Akt Nowych

Ministerstwo Wyznań Religijnych i Oświecenia Publicznego, sygn. 1431, 376.

Biblioteka Prezydencka w Petersburgu

Rossijskij Gosudarstwiennyj Istoriczeskij Archiw w Petersburgie (dawniej Centralnyj Gosudarstwiennyj Istoriczeskij Archiw w Leningradie), Sowiet ministrow (1905-1917), fond 1276.

\section{Źródła drukowane}

Seweryniak H., Święte Oficjum a mariawici, Płock 2014.

\section{Wydawnictwa statystyczne}

Rocznik Statystyczny Rzeczypospolitej Polskiej, GUS, Warszawa 2020.

Wyznania religijne w Polsce 2015-2018, GUS, Warszawa 2019.

Prasa

„Dzieje Królestwa Bożego na Ziemi” 1936.

„Głos Staro-Katolicki” 1938, 1939.

„Jednodniówka Mariawicka” 1923, 1926, 1935.

„Królestwo Boże na Ziemi” 1928, 1930, 1937.

„Młody Mariawita” 1937, 1938.

„Przegląd Powszechny” 1926.

\section{Opracowania}

Górecki A., Mariawici i mariawityzm - narodziny i pierwsze lata istnienia, Warszawa 2011. Grelewski S., Wyznania protestanckie i sekty religijne w Polsce współczesnej. Zarys stanu prawnego wyznań religijnych $w$ Polsce, Sandomierz 1935.

Mazur K., Mariawityzm w Polsce, Kraków 1991.

Nowowiejski A.J., Płock. Monografia historyczna, wyd. II, Płock 1930.

Podgórski R.A., Starokatolicki Kościót Mariawitów. Studium historyczno-socjologiczne, Kraków 1998.

Prasa Królestwa Polskiego w opinii władz cenzury rosyjskiej (1901-1914). Dokumenty, wstęp, oprac. i przekł. J. Kostecki, M. Tobera, Warszawa 2013.

Rybak S., Mariawityzm. Dzieje i współczesność, Warszawa 2011.

Sawicki J., Stan prawny Kościoła Mariawitów, „Gazeta Administracji i Policji Państwowej" 7 (1935).

Skwara G., Mariawici. Szkic historyczny ruchu mariawickiego w Polsce, Płock 1925.

Szejnman M.M., O stanowisku Watykanu w kwestii polskiej w końcu XIX - początku $X X$ w., „Studia z Dziejów Kościoła Katolickiego” 2 (1960) 2. 
Świątkowski H., Wyznania religijne w Polsce ze szczególnym uwzględnieniem ich stanu prawnego. Część I. Wyznania i związki religijne, Warszawa 1937.

Toborek T., Problem mariawityzmu na łamach „Gońca Częstochowskiego”. Echa zajść w Strykowie w 1906 r., „Rocznik Łódzki” 45 (1998).

Warchoł E., Starokatolicki Kościół Mariawitów w okresie II Rzeczypospolitej, Sandomierz 1997. 